Prof. dr. Ana Krajnc

Filozofska fakulteta

Univerze $v$ Ljubljani

\section{ŠTUDIJ ANDRAGOGIKE IN IZOBRAŽEVANJE ANDRAGOGOV}

\title{
POVZETEK
}

Več je bilo vzrokov za to, da je v povojnem obdobju primanjkovalo izobraženih ljudi. Država je načrtno in pospeřeno razvijala industrijo, zato je primanjkovalo kvalificiranih delavcev. Vojno obdobje je marsikomu preprečilo dokončanje šolanja. Poleg tega so bili izobraženci pogostejše žrtve vojne kot preostalo prebivalstvo. Zato je bilo na zavodih za zaposlovanje povpraševanje po usposobljenih delavcih večje kot ponudba. Posledično se je izobraževanje odraslih v praksi hitro razvijalo. Praktiki so iskali strokovno podporo in ustrezno literaturo.

Leta 1956 so v Zagrebu na Filozofski fakulteti uvedli v okviru študija pedagogike prva predavanja andragogike v takratni Jugoslaviji. Profesor Mihajlo Ogrizović kot nosilec predmeta je študij v naslednjih letih podprl z objavo prvih knjig s področja andragogike: Metode obrazovanja odraslih in Problemi andragogije. Leta 1960 je nastala katedra za andragogiko na Filozofski fakulteti v Beogradu (profesorja Dušan Savičević in Borivoj Samolovčev). Za raziskovanje na področju izobraževanja odraslih sem se odločila med službovanjem na Inštitutu za sociologijo (1967), ko sem se pridružila takrat pri nas prvi mednarodni komparativni raziskavi Izobraževanje odraslih, socialna mobilnost in družbena participacija. S predavanji obče andragogike in andragoške didaktike smo v Ljubljani začeli leta 1972 na Oddelku za pedagogiko Filozofske fakultete. Leta 1976 je študij andragogike postal ena od študijskih smeri na oddelku. V študijskem letu 1993/94 smo uvedli samostojni enopredmetni študij andragogike. Ministrstvo za šolstvo in šport je novi študijski program potrdilo v okviru evropskega projekta Tempus.

Na oblikovanje študijskih programov so vplivali najbolj znani inštituti in oddelki za izobraževanje odraslih v razvitem svetu (Oddelek za andragogiko Univerze v Montrealu, Evropski Bureau for Adult education v Londonu, Wellington College $v$ Oxfordu, Institute for Andragology v Amsterdamu, Oddelek za andragogiko Karlove univerze v Pragi itd.). To nam je zagotavljalo, da je študij na mednarodni ravni. Enoletna postdoktorska specializacija na Inštitutu v Torontu (1971) je priprave na predavanja dokončno zaokrožila. Strokovna in znanstvena literatura iz andragogike se je pomnožila. Andragogika je dobila svoje mesto $v$ nacionalnem raziskovalnem programu. Vzporedno smo raziskovali v mednarodnih raziskavah prek UNESCA, ICAE (International Council for Adult Education) in projektov EU. Študij andragogike se je ponovno preoblikoval v okviru bolonjske reforme visokega šolstva $v$ zadnjih letih.

Ključne besede: potrebe po izobraževanju odraslih, povpraševanje po strokovnjakih večje od ponudbe, študij andragogike, mednarodni vplivi na študijski program, odnos med andragoško prakso in teorijo, raziskovanje v andragogiki in mednarodno sodelovanje

UDK:374.7:378

V obdobju po drugi svetovni vojni se je družba v Jugoslaviji načrtno spreminjala iz kmetijske v industrijsko. Simbol takratne ideologije je bil tovarniški delavec ob stroju. Kmetijstvo in kmečko prebivalstvo sta imela nizek družbeni položaj. Celotna politika napredka je bila grajena na industriji in industrializaciji države. Razvoj je tekel po petletnih načrtih (»petletkah«). Priliv kmečkega prebivalstva v industrijo, selitev iz vasi v mesta (urbanizaci- ja) sta bila tako nagla, da sta vključevala tudi postopke prisilnega zaposlovanja $\mathrm{v}$ tovarnah. Ljudje so dobivali na dom odločbe občinskega urada za notranje zadeve, kdo, kdaj in kje naj se javi na delo v tovarni. Kolektivna volja je bila nad osebno.

$\mathrm{V}$ praksi se je izobraževanje odraslih $\mathrm{v}$ raznih oblikah (večerne šole, kulturna društva Svoboda, usposabljanje delavcev v tovarnah) naglo razraščalo in potrebe po teoriji so se 
stopnjevale. Izobraževalce odraslih (delovodje, srednji strokovni kader, inštruktorje) je bilo treba usposobiti za ustrezno izobraževalno dejavnost. Veliko truda je $\mathrm{v}$ to $\mathrm{v}$ šestdesetih letih vlagal Ivan Bertoncelj.

Število zaposlenih v industriji je naglo naraščalo in $s$ tem tudi število ljudi kmečkega rodu, ki jih je bilo za delovno mesto šele treba pripraviti. Potrebe po izobraževanju odraslih so bile množične in so iz dneva $\mathrm{v}$ dan naraščale. Pri nas se je ponovila podobna družbenoekonomska in tehnološka situacija, kot je bila v Severni Ameriki ali Zahodni Evropi konec 19. in v začetku 20. stoletja (pred prvo svetovno vojno). Ameriški avtor Lindemann, ustanovitelj andragoške teorije in znanosti, je izhajal prav iz njihovega takratnega naglo rastočega množičnega izobraževanja odraslih. Po prvih dveh petletkah industrijskega razvoja so bila politična prizadevanja za sistemsko ureditev izobraževanja odraslih $\mathrm{v}$ Jugoslaviji vedno bolj močna. Iz povojnih kulturno-prosvetnih društev Svoboda so nastajale ljudske in delavske univerze. Na podlagi sprejetja zakona so se med letoma 1957-59 v vsaki od republik ljudske in delavske univerze povezale v zvezo delavskih univerz. Na Oddelku za pedagogiko Filozofske fakultete Univerze v Zagrebu so leta 1956 že uvedli predavanja iz andragogike (prof. Mihajlo Ogrizović). Iz vedno bolj obsežne prakse izobraževanja odraslih se je razvijala za nas takrat nova veda: andragogika (Krajnc, 1978/1: 169-171).

\section{KAKO SE JE ZAČELO V SLOVENIJI? ŠESTDESETA LETA: VEČJA PONUDBA SLUŽB KOT POVPRAŠEVANJE}

$\mathrm{V}$ času ekstenzivnega razvoja industrije in množičnega zaposlovanja v Jugoslaviji v začetku šestdesetih let prejšnjega stoletja so naraščale potrebe po poklicni izobrazbi. Možnosti za zaposlitev je bilo še preveč. Najbolj množično so zaposlovali delavce. Cenjeni so bili kvalificirani delavci. Poklic je zaposlenemu določal položaj v piramidalni strukturi podjetja.

Govorimo o obdobju množičnega zaposlovanja. Tovarne in gradbena podjetja so odhajala $\mathrm{z}$ avtobusi novačit delavce $\mathrm{v}$ druge republike Jugoslavije, ker je domačih primanjkovalo. V podobni situaciji so bile tudi sosednje države. Rade so sprejemale delavce iz drugih držav (južne Evrope in Turčije), da bi zadovoljile potrebe industrije po delavcih.

To je bil za zavode za zaposlovanje poseben čas. Osrednji problem je bilo poklicno

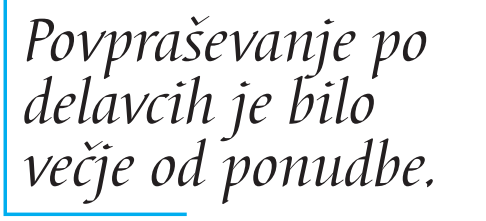
usmerjanje ali poklicna orientacija. Že osnovnošolcem so svetovali, kateri poklic bi bil za nekoga najbolj primeren. Poklic je pomenil preživetje: zaslužek, socialni položaj in varnost.

Po podatkih iz leta 1961 v Sloveniji 40 odstotkov generacije ni dokončalo osemletke. Podoben delež je ostal samo z osemletko. Le manjši delež je šel v poklicne in srednje šole. Kot psihologinja na zavodu za zaposlovanje sem se znašla v primežu med ponudbo delovnih mest in povpraševanjem na eni strani ter skupinami mladih ljudi brez poklicne izobrazbe. Ko so fantje prihajali od vojakov, so se takoj zglasili na zavodu za zaposlovanje. Psihološki testi so mi potrdili njihove sposobnosti, pridobljena izobrazba pa tega ni potrjevala, ker je bila zelo nizka. Vladala je mentaliteta, da »zakaj bi se učil, se mučil, če lahko dobiš službo že takoj po opravljeni šolski obveznosti (15 let starosti) ali po odsluženi vojski (pri 19 letih)«. Ponekod zunaj večjih mest $\mathrm{z}$ razvito kulturno tradicijo so prav možnosti za zaposlitev zmanjševale težnje po nadaljevanju šolanja. Tak primer je Prekmurje. V Muri so zaposlovali mlade tudi z nedokončano osemletko (s sedmimi ali šestimi razredi osnovne šole), zato se jim nadaljevanje šolanja ni zdelo tako pomembno. Skozi desetletja je povprečno število šol na prebivalca vedno bolj zaostajalo za preostalo 
Slovenijo. In še drugi nekoliko poznejši primer z nasprotnega konca Slovenije. Igralnica v Gorici je zaposlovala mlade s srednjo šolo. Tudi že začeti študij so mnogi opustili, ker je bilo zaposlitev enostavno dobiti tudi brez diplome. Število diplomantov z visoko izobrazbo je tam začelo zaostajati.

Neposredne izkušnje sem dobila na izpostavi Zavoda za zaposlovanje Ajdovščina. Naše zaledje zaposlovanja so bile močne tovarne: Fructal, Tekstilna tovarna, pohištvena industrija Lipa, Tovarna poljskih orodij Batuje, Gradbeno podjetje Primorje, Kovinska Ajdovščina in druge tovarne v širšem zaledju (Gorica). Povpraševanje po kvalificiranih delavcih je naraščalo, a pogosto mu nismo mogli zadostiti, čeprav smo imeli na spisku mlade, sposobne in zdrave ljudi, a brez poklica. Nesmiselno se mi je zdelo psihološko testiranje sposobnosti prijavljenih delavcev, če so bili brez poklica. Kot svetovalka sem se začela spraševati, kaj bi se ti mladi ljudje še lahko naučili, si pridobili poklic, izobrazbo. V sedanjem stanju bodo težko šli skozi življenje. Vedno bolj sem se vrtela ob misli na izobraževanje odraslih. To se mi je zdel edini možni izhod, edina rešitev za brezposelne brez poklica. Bila sem sveže pečena diplomantka tudi pedagogike, a moj študij ni omenjal izobraževanja odraslih. Predmeti so bili osredotočeni na šolsko pedagogiko. Z metodologijo pedagoškega raziskovanja, ki smo jo štiri leta poslušali pri profesorju Vladu Schmidtu, smo bili diplomanti dobro oboroženi za odkrivanje novih področij in prodiranje $v$ nove pojave. Pri profesorju Stanku Gogali smo se prepojili s pedagoškim optimizmom in to je bila dobra popotnica na novih poteh. Okolju, v katerem sem živela, bi se $\mathrm{v}$ tistem obdobju zamisel, da naj se odrasli še izobražujejo, zdela dokaj nenavadna in nesprejemljiva, čeprav je pred prvo svetovno vojno imelo močno tradicijo kulturno-izobraževalnih društev. To sem kmalu začutila $\mathrm{v}$ pogovoru s predsednikom mestne občine in na nekaterih sestankih. Odločila sem se, da sama iščem dalje.

Potrebe po kvalificiranih delavcih so ob razvijajoči se industriji naraščale in so jih čutili tudi drugi. V Ljubljani je o izobraževanju za delo predaval Bertoncelj. Nastajale so delavske in ljudske univerze. V tovarnah so organizirali priučevanje in usposabljanje delavcev. Kot izhod iz sile so nastale tako imenovane $»$ notranje kvalifikacije« v podjetjih. V Ljubljani je že več let delovala Dopisna delavska univerza. Občasno so se ob rednih šolah organizirale večerne šole za odrasle. V Ljubljani je nastala Zveza delavskih univerz. Vodila jo je Tilka Blaha in pozneje Marjan Lah. Na zavodu je delovala posebna skupina za izobraževanje odraslih pod vodstvom Jožeta Valentinčiča. Kmalu nato so ustanovili Andragoško društvo Slovenije po zgledu društev v drugih republikah Jugoslavije. Na ljubljanski univerzi je bil zaposlenim dostopen izredni študij. Z njim so nadoknadili vojna leta. Strokovnjakov je povsod primanjkovalo. Visoka politična šola CK Slovenije je imela več let samo izredni študij za izbrane ljudi na položajih. Izobraževanje odraslih se je pojavljalo v vseh socialnih plasteh prebivalstva.

\section{OPAZOVANJE ANDRAGOŠKE PRAKSE IN SODELOVANJE $Z$ ANDRAGOŠKIMI USTANOVAMI}

Od takrat naprej, ko sem se odločila za področje izobraževanja odraslih, je to postalo moj osrednji interes in žarišče vseh akcij. Še v času službovanja na zavodu za zaposlovanje v Ajdovščini sem tesno sodelovala $\mathrm{z}$ znano direktorico tamkajšnje delavske univerze (ene od treh najboljših v Sloveniji) Miro Novak. Spoznala sem osnovni ritem in izobraževalne vsebine te in drugih delavskih univerz. Na srednji šoli so bili tudi oddelki za odrasle (večerni tečaji). V Gorici sem sodelovala z direktorjem delavske univerze Rajkom Slokarjem.

Ko sem kot raziskovalka prišla v novo službo na Inštitut za sociologijo v Ljubljani, sem do- 
bila stik z republiškimi organizacijami: Zvezo delavskih univerz Slovenije z Marjanom Lahom na čelu, Zavodom za produktivnost dela, Andragoškim društvom Slovenije (s predsednico Tilko Blaha), Oddelkom za izobraževanje odraslih pri republiškem zavodu za šolstvo (predstojnik je bil Jože Valentinčič), republiškim zavodom za zaposlovanje (Jan Makarovič), Zavodom za zaposlovanje Ljubljana (Virant, Pavliha) in Oddelkom za izobraževanje pri republiškem odboru Zveze sindikatov Jugoslavije, Združenjem izobraževalnih centrov $\mathrm{v}$ industriji. Trendi in prerez prakse so mi postajali vedno bolj jasni. Udeleževala sem se konferenc in posvetov o izobraževanju odraslih, marljivo poslušala, o čem govorijo predavatelji in udeleženci. Obrisi prakse so se postopoma povezali. Vzporedno sem prebirala vse dosegljive tekste o tej temi. Zelo požrtvovalno je na terenu usposabljal izobraževalce odraslih Ivan Bertoncelj, zaposlen pri takratnem Zavodu SRS za strokovno izobraževanje. Žal je kmalu potem, ko sva se srečala, odšel kot UNESCOV strokovnjak v Afriko.

Proučila sem koncept funkcionalnega izobraževanja in industrijske pedagogike na Visoki šoli za organizacijo dela v Kranju (Kejžar, Lorenčič). Na Reki sem poiskala avtorja industrijske pedagogike Martina Petančiča, prebrala njegove članke in obsežno knjigo Industrijska pedagogika iz leta 1968. Poiskala sem vire za študij kadrologije v Zagrebu. Brez vsega tega se pozneje ne bi mogla odločiti, kaj naj gre v študijski program andragogike in kaj ne (Miklič, Bertoncelj, Kejžar, 1969).

Spoznala sem ljudi iz andragoških ustanov v drugih, manjših krajih Slovenije. Postopoma so $\mathrm{z}$ raznih koncev prihajala vabila za predavanja in sodelovanje. Vedno sem se jim odzvala in sprejela sodelovanje, razen če res nisem mogla zaradi drugih obveznosti. To je bilo obdobje pridobivanja dragocenih strokovnih izkušenj. Iz mojih letnih poročil o delu izhaja, da sem imela na leto v povprečju 40 javnih nastopov. Razen referatov na konferencah in predavanj sem občasno nastopala tudi na radiu Ljubljana. To je bila dobra priprava za poznejše pedagoško delo na Filozofski fakulteti, na Oddelku za pedagogiko.

Spremljanje prakse mi je dalo možnosti, da študijski program za andragogiko prilagodim slovenskim razmeram, izberem iz teorije in znanosti, kar ustreza našim potrebam. Tako bi študij najbolj koristil razvoju andragoške prakse.

Na sodelovanje s prakso pa $\mathrm{v}$ akademskih krogih niso gledali z naklonjenostjo. Ni bilo dovolj prestižno. Zato ga na fakulteti raje nisem poudarjala.

En del vpogleda $v$ prakso je bil tudi študij andragogike na drugih univerzah: $v$ Bostonu (Knowjes), Sao Paulu (Freire), Pragi (Kamil Škoda), Zagrebu (Ogrizović), Beogradu (Savičević), Rimu (Filipo De Sanctis), Torontu (Robin Kidd), Tübingenu (Günter Dohmen), Firencah (Paolo Federighi), Utrechtu itd. Nosilci študija so se mi odkrili kot veliki humanisti. Še danes imam jasne predstave o njih. Vplivali so na moja stališča in vrednote. Kar sem iskala, ni bila samo študijska vsebina. Glede na razlike v okolju so bile tudi med študijskimi predmeti velike razlike. A cilji študija so bili zelo podobni: usposobiti kvalitetne strokovnjake za izobraževanje odraslih, izobraziti izobraževalce odraslih.

\section{PRVA MEDNARODNA KOMPARATIVNA RAZISKAVA "IZOBRAŽEVANJE ODRASLIH, SOCIALNA MOBILNOST IN DRUŽBENA PARTICIPACIJA«}

Vsa ta nastajajoča praksa izobraževanja odraslih naj bi dobila svoj izraz v raziskovanju stvarnosti in se povezala $\mathrm{v}$ teorijo. Brez posplošitev in odkrivanja temeljnih načel in lastnosti pojavov začne praksa postopoma hirati, če se ne revitalizira $\mathrm{z}$ raziskovanjem. Zato sem iskala dalje in se povezovala s podobno mislečimi $\mathrm{v}$ praksi izobraževanja odraslih in $\mathrm{v}$ družbenih vedah. $\mathrm{Z}$ zavoda za zaposlovanje sem odšla 
v službo na Inštitut za sociologijo v Ljubljani (1964). Tri leta po prihodu (1967) sem se kot raziskovalka, koordinatorica za Slovenijo, pridružila mednarodni študiji »Izobraževanje odraslih, socialna mobilnost in družbena partiRaziskovalci smo se veliko učili. cipacija«. V raziskavi so sodelovali še trije kolegi z Inštituta za sociologijo: Zdravko Mlinar, Janez Jerovšek in Mišo Jezernik. Raziskovalni tim se je vsakič sestal v drugi državi. Leta 1968 (Dubčkovo leto) smo se zbrali na Karlovi univerzi v Pragi. Nato na univerzi v Utrechtu itd. Imeli smo priložnost, da neposredno doživimo raziskovalno in pedagoško delo na velikih svetovnih univerzah. Raziskovalci smo se veliko učili.

Raziskavo je koordinirala Hamilton University iz Kanade, sodelovale pa so še univerze iz ZDA (University of Oregon), Poljske (Univerza v Varšavi), Holandije (Univerza v Utrechtu) in Karlova univerza v Pragi. S posebnim vprašalnikom sem v okviru te raziskave zbrala empirične podatke za doktorat. Leta 1969 sem na povabilo predstojnika Oddelka za pedagogiko Vlada Schmidta kot asistentka prišla delat na Filozofsko fakulteto. Menil je, da se izobraževalne vede glede na razvoj morajo razširiti s tem, da dodajo $\mathrm{v}$ program še $\gg$ adultno pedagogiko«. V konstruktivnih odnosih zaupanja, medsebojne podpore in tovariškem vzdušju je bilo užitek delati. Predstojnik mi je dal svobodo ustvarjanja in iskanja. Strinjal se je, da bi se predmet imenoval andragogika, ker je bilo tako tudi na univerzi v Zagrebu (profesor Mihajlo Ogrizović, 1956) in univerzi v Beogradu (profesor Dušan Savičević in profesor Bora Samolovčev, 1961). Povezala sem se z vsemi vidnimi ustvarjalci domače prakse in prek mednarodne raziskave $\mathrm{z}$ avtorji $\mathrm{v}$ tujini. Odpiral se nam je zelo širok prostor delovanja. V komisiji za doktorat sem imela tri aktivne člane: profesorja sociologije na Pravni fakulteti Jožeta Goričarja, profesorico pedagoške sociologije na Oddelku za pedagogiko Filozofske fakultete v Ljubljani Milico Bergant in

predstojnika oddelka, profesorja metodologije in zgodovine šolstva in pedagogike Vlada Schmidta. Mednarodna komparativna raziskava se jim je zdela zelo zanimiva in besedilo doktorata so vsi trije kritično premleli. Praktično sem zagovarjala doktorat najprej pred vsakim od njih posebej in potem še $\mathrm{v}$ formalnem proceduralnem zagovoru pred komisijo (1971). Del besedila doktorata sem objavila v Kanadi, na Ontarijskem inštitutu za raziskovanje izobraževanja (OISE) leta 1973 pod naslovom »Adult Education and Social Participation «, in v knjigi »Izobraževanje - naša družbena vrednota« pri Delavski enotnosti v Ljubljani leta 1978.

\section{KAJ IE VPLIVALO NA OBLIKOVA- NJE ŚTUDIJSKEGA PROGRAMA ZA ANDRAGOGIKO NA FILOZOF- SKI FAKULTETI V LJUBLJANI?}

\section{Teoretične smeri in stiki z znanstveniki na tujih univerzah in inštitutih}

Strnjen intenzivni program krajše specializacije (dva meseca) za izobraževanje odraslih pri Združenih narodih v Ženevi leta 1970 je odprl nove vidike učenja glede na lokalni in nacionalni razvoj. Izobraževanja odraslih ni bilo več mogoče gledati zgolj z ozkega vidika dela in $\mathrm{v}$ funkciji dela, ampak vseh potreb neke socialne skupnosti in posameznika. Kulturna tradicija in razvojni načrti neposredno vplivajo na izobraževanje odraslih. Eden glavnih predavateljev na tej specializaciji je bil Leo Förnig, direktor Mednarodnega pedagoškega inštituta v Ženevi. Zanj je bila značilna trditev: »Slabih učencev ni. Slabi so lahko le učitelji.«

Podrobneje je razložil, kako pomembno je, da ima učenec sebi primernega učitelja. Misel, ki smo jo deset let pozneje srečali ob mednarodni delegaciji ICAE na Kitajskem.

Kanadska štipendija za postdoktorski študij (takoj po zagovoru doktorata) na Ontarijskem inštitutu za raziskovanje izobraževanja (OISE) Univerze $\mathrm{v}$ Torontu mi je omogočila neposredna 
srečanja z vidnimi raziskovalci in teoretiki področja. Moj mentor na postdoktorskem študiju je bil profesor Robin Kidd, predstojnik Oddelka za izobraževanje odraslih omenjenega inštituta. $\mathrm{Z}$ dodatno štipendijo sem obiskala še druge večje univerze v Kanadi. Na Univerzi v Montrealu je velik vtis name napravil Pier Blondel z velikim oddelkom za andragogiko. Tu je imela svoj vpliv francoska kulturna tradicija. Ta priznava pedagogiko kot posebno znanost ali disciplino. Angleško govoreče univerze $\mathrm{z}$ anglosaško tradicijo, kot so University of Calgary, Windsor University in na zahodu v Vancouvru University of British Columbia, pa niso ločevale pedagogike kot znanosti in so tudi znanstveno področje izobraževanja odraslih pragmatično poimenovale »adult education «. Sodelovala sem z Alenom Toughom, glavnim raziskovalcem učnih projektov in avtorjem novih metodoloških pristopov, Alenom Thomasom in Malcolnom Knowelsom. Prav v tem letu je izšlo znamenito delo Paola Freireja »Pedagogika zatiranih« (Pedagogy of the Oppressed). Osebno srečanje z njim je močno vplivalo na moja razmišljanja in teoretični koncept pri pripravi študijskega programa za andragogiko na Filozofski fakulteti v Ljubljani. Med mojim postdoktorskim študijem v Torontu je Robin Kidd organiziral svetovno konferenco v Ottawi (1972). Na njej so se zbrali raziskovalci, praktiki in teoretiki izobraževanja odraslih z vsega sveta. Ustanovili smo Mednarodni svet za izobraževanje odraslih (International Council for Adult Education) s sedežem v Torontu. Kot svetovna organizacija je kmalu po nastanku dobila poseben svetovalni status pri UNESCU. Več mandatov sem bila članica upravnega odbora in strokovne povezave so se razširile po vsem svetu. Vsakih pet let smo imeli svetovno konferenco, vedno na drugi celini. Danes organizacijo ICAE vodi znani mednarodni strokovnjak Paul Belange. Na VI. svetovni UNESCOVI konferenci za izobraževanje odraslih CONFITEA 2009 v Belo Horizonteju v Braziliji je Paul Belange predstavil projekcijo razvoja izobraževanja odraslih in potrdil, kako nujen je dialog med vladnimi in nevladnimi organizacijami, civilno družbo. Prek sodelovanja v ICAE sem dobila boljši pregled nad študijem izobraževanja odraslih in prakso v Latinski Ameriki, Avstraliji, Aziji in Afriki. Od prve raziskave dalje smo vedno sodelovali v raznih mednarodnih študijah. To nam je dalo podlago za razvoj komparativne andragogike tudi pri nas.

Naše raziskovalno delo se je od leta 1976 do 1988 povezovalo z mednarodnim timom pri UNESCOVEM projektu »Sistemi izobraževanja odraslih v Evropi« (The Sistems of Adult Education in Europe). V vsaki državi so raziskovalci pripravili posebno študijo sistema izobraževanja odraslih in jo objavili v posebni UNESCOVI publikaciji.

V samostojni Sloveniji smo zasnovali enega prvih TEMPUSOVIH projektov EU »Obnova študija andragogike v Sloveniji« (1992-1994). Njegova koordinatorica je bila Katedra za andragogiko na Oddelku za pedagogiko, partnerske univerze pa so bile: Univerza v Surreyu (Peter Jarvis), Anglija; Univerza v Utrechtu (Peter Hage), Nizozemska; Univerza v Bambergu (Jost Reischman), Nemčija; St. Patrick College (Liam Carey), Irska. Ob sodelovanju Z več oddelki smo dopolnili naš študijski program na Filozofski fakulteti. Dobili smo tudi gostujoče profesorje. Na strnjena predavanja smo poleg rednih študentov andragogike vabili tudi druge strokovnjake iz neposredne andragoške prakse. Predavanja, diskusije in strokovne knjige profesorjev z drugih univerz, ki so jih študenti imeli priložnost tudi osebno spoznati v Ljubljani, so neposredno vplivali na spremembe in dopolnitve študijskega programa.

\section{SLOVENSKE ZNANSTVENE RAZISKAVE IN ŠTUDIJE V ANDRAGOGIKI}

Diplomanti pedagogike v naših generacijah so bili dobro usposobljeni za empirično raziskovanje in znanstveno delo. Kot sem že omeni- 
la, smo imeli pri profesorju Vladu Schmidtu metodologijo pedagoškega raziskovanja vseh osem semestrov in prve štiri semestre statistiko pri profesorju Vogelniku. Na tej podlagi je bil ustanovljen Pedagoški inštitut, ki pa se je v raziskovanjih omejih na pedagogiko.

Raziskovanje s področja andragogike se je začelo na sociološkem inštitutu v okviru velikega mednarodnega projekta »Izobraževanje odraslih in družbena participacija« (1967-1972), ob kadrovski spremembi pa se je preneslo na Oddelek za pedagogiko Filozofske fakultete v Ljubljani. S tem ko se je andragogika uvrstila med študijske predmete, se je žarišče andragoških raziskav še utrdilo. Katedra za andragogiko je imela od srede sedemdesetih let prejšnjega stoletja pri ministrstvu za znanost financiran poseben raziskovalni program. Občasno so se pridružili še raziskovalci iz sociologije in psihologije.

Žarišče za andragoške raziskave se je razširilo $\mathrm{z}$ delom za diplomske in magistrske naloge. Prve so zagovarjali sredi sedemdesetih let. Bolj obsežne raziskave so bili doktorati znanosti. Na katedri je potekala raziskava sistema izobraževanja odraslih za vso takratno državo. Nadaljevalo se je z raziskavami o motivaciji odraslih za izobraževanje, disleksiji odraslih in učnih strategijah, potrebah starejših po znanju, modelih uresničevanja vseživljenjskega izobraževanja, izkustvenem učenju itd. Nekatere analize so pripravili na Zvezi delavskih univerz, pri Andragoškem društvu Slovenije in Zvezi izobraževalnih centrov.

$\mathrm{V}$ osemdesetih letih je del andragoških raziskav potekal na Pedagoškem inštitutu (Zoran Jelenc, raziskava o neformalnem izobraževanju).
Sodelovanje Katedre za andragogiko v UNESCOVEM timu za komparativno andragogiko pri desetletje trajajoči raziskavi (1976-86) »Sistemi izobraževanja odraslih v Evropi« pod vodstvom Karlove univerze v Pragi in raziskovalnega vodje Premysla Majdla je dalo velik raziskovalno znanstveni prispevek. Katedri se je pridružil Ilija Mrmak in razširil raziskovanje na metodiko družbenopolitičnega izobraževanja in industrijske andragogike. Raziskave o poklicnem izobraževanju odraslih so na Oddelku postale domena Janka Muršaka.

Ko so se od srede osemdesetih let dalje andragoški katedri pridružile nove docentke (Nena Mijoč, Dušana Findeisen, Vida Mohorčič, Nives Ličen, Sabina Jelenc, Sonja Kump in Monika Govekar), se je raziskovanje razcepilo v več samostojnih področij, kot so: komparativna andragogika, andragoško didaktične raziskave, zgodovina izobraževanja odraslih, izobraževalno svetovanje, socio-kulturna animacija, izobraževanje starejših in družinska andragogika. Evropska raziskava EURO DELPHI (1993-1996) (koordinatorica raziskave Univerza v Luevnu, Belgija, koordinatorica za Slovenijo Ana Krajnc) je uvedla novo metodologija (metodo delphi) in poglobila raziskovanje o družbeni funkciji izobraževanja odraslih v sodobnih razmerah.

Nosilci raziskav o izobraževanju starejših so postali vodilni strokovnjaki mreže 45 univerz za tretje življenjsko obdobje v 43 krajih Slovenije, združeni v Slovenski univerzi za tretje življenjsko obdobje. Posebna raziskava s tega področja se je v zadnjih letih izvajala tudi na Fakulteti za družbene vede Univerze v Ljubljani (Kump,

Po osamosvojitvi Slovenije je bil ustanovljen Andragoški center Slovenije (1992), raziskovalno-razvojna organizacija, za katero smo se pri državni upravi bojevali že nekaj desetletij in končno uspeli. Z raziskavami so spremljali novorazvijajočo se andragoško prakso. Sledile so raziskave o študijskih krožkih, borzah znanja, programih za usposabljanje mladih (PUM), izobraževanju odraslih v srednje- in vzhodnoevropskih državah, motivaciji za izobraževanje, mreži andragoških ustanov, poklicnem izobraževanju odraslih in kakovosti izobraževanja. Danes Andragoški center žal nima več raziskovalne funkcije, čeprav si težko predstavljamo, koliko časa in kako kakovostno bo razvojno delo, če ne bodo sproti raziskovali dejanske stvarnosti v andragoški praksi. 
Jelenc). Sonja Kump je bila leta 2003 izvoljena v naziv višjega znanstvenega sodelavca.

$\mathrm{Na}$ področju izobraževanja odraslih se je v zadnjih desetletjih toliko dogajalo, da je študijski program postal živo telo nenehnih sprememb in novosti.

Pomembno vlogo v razpravi o pomenu izobraževanja $v$ neki družbi in za posameznika je imela evropska mednarodna študija EURO DELPHI »Prihodnost izobraževanja odraslih v Evropi« (1993-1996). Koordinatorica tega projekta EU je bila Univerza Lueven iz Belgije, v njej pa so sodelovali raziskovalci iz vseh takratnih 12 članic EU ter Češka, Estonija in Slovenija kot nekdanje socialistične države. Pomembna ugotovitev raziskave je bila, da trendi sodobnega razvoja v izobraževanju odraslih ne poznajo nacionalnih meja in so splošni. Konfiguracija empiričnih podatkov je bila podobna tako pri nekdanjih socialističnih državah kot pri članicah EU. Raziskovalci so odkrivali cilje in pomen izobraževanja odraslih na socialni in individualni ravni ter trende razvoja. Ugotovili so, da pridobivanje poklicnih znanj ni več v ospredju izobraževanja odraslih. Večji poudarek je na znanju za obvladanje družine in doma, računalniških znanjih, znanju za sodelovanje v kulturi in osebnostno rast, znanju za ohranjanje zdravja in varnost, znanju za aktivno državljanstvo in pridobivanje družbene moči, iskanje smisla življenja, znanju o medosebnih odnosih in naučiti učiti se. Podobne rezultate so pokazale tudi nekatere druge sočasne raziskave zunaj Evrope. Pod vplivom sprememb v informacijski družbi so se cilji izobraževanja odraslih bistveno spremenili.

Posebno mesto imajo domače raziskave in mednarodno sodelovanje pri razvoju izobraževanja starejših. Univerza v Ulmu (Karmen Stadelhofer), središče »Učenje v poznejšem življenju« (Learning in Later Life, LILL) in istoimenska revija ter strokovne konference podpirajo razvoj novega področja izobraževanja starejših kot nujne podlage za dejavno starost. V okviru tega področja poteka več projektov EU, ob njih se krepita tudi mednarodno sodelovanje in izmenjava spoznanj.

\section{STROKOVNA LITERATURA IN PRVA SLOVENSKA REVIJA ZA IZOBRAŽEVANJE ODRASLIH "ANDRAGOŠKA SPOZNANIA"}

Ideja permanentnega ali vseživljenjskega izobraževanja J. A. Komenskega v delu Pampadeia je postala neke vrste izhodiščna literatura. »Vsaka doba starosti je namenjena učenju in vsem ljudem so dani isti cilji za življenje in za učenje ... Ta (nižja) šola traja in mora trajati vse življenje, ker je samo življenje tudi šola. Vsaka življenjska doba je primerna za učenje nečesa drugega, in če zamudimo pravi trenutek, lahko veliko izgubimo.«(Vidmar, 1995: 50.)

Najstarejšo tradicijo prosvetnega dela je mogoče zaslediti v priročnikih prosvetitelja Matije Vertovca (1784-1851), to so bili priročniki za izobraževanje prebivalstva in članki v tedanjem časopisju. V njih odkrivamo značilnosti izobraževanja odraslih kot prosvetnega dela v prvi polovici 19. stoletja (gradivo za simpozij o Matiji Vertovcu, 1984).

Prvi slovenski deli, ki ju štejemo za teoretično izhodišče domače andragogike, sta Ozvaldova »Kulturna pedagogika« in Franja Žgeča »Vzgoja ljudskih množic«. Obe poudarjata osebnostno rast in razvoj odraslih, izobraževanje odraslih postavljata širše, tako da služi življenju, osebni sreči in napredku (Žgeč, 1923; Ozvald, 1927). Oba sta opazila, kako se je predmet pedagogike kot znanosti z razvojem industrije ter hitrim razraščanjem poklicnega in strokovnega srednjega šolstva na prelomu iz 19. v 20. stoletje vedno bolj ožil na proučevanje pouka in šolskega sistema. Širši vzgojno-izobraževalni programi za odrasle, kulturno-prosvetno delo, kulturno-prosvetna društva 
so zbledeli in ostali ob strani, ker se je spričo naglega razvoja industrije pedagogika bolj osredotočila na hitro rastoči sistem poklicnega šolstva. Oba utemeljujeta širše cilje znanosti o vzgoji in izobraževanju in potrebo po osebnostnem razvoju ljudi. Od tod tudi ime »kulturna pedagogika«. Ozvald, takrat profesor pedagogike na Filozofski fakulteti v Ljubljani in predstojnik Oddelka za pedagogiko, je bralca že v uvodu opozoril, da če išče v njegovi knjigi recepte, je bolje, da jo že na začetku odloži, saj jih v njej ne bo dobil. Če išče teorijo in globlji vpogled v človekov razvoj, pa naj nadaljuje (Ozvald, 1927: 4).

Franjo Žgeč je »vzgojo širokih ljudskih množic« povezal s podeželskim življenjem: kakovostjo družinskega življenja, vzgojo otrok in napredovanjem kraja. Preveč je bilo zaostalih podeželskih okolij, ki niso dosegala ravni poklicne izobrazbe v mestih. Menil je, da ima premalo ljudi možnost za razvoj in primerno izobrazbo. To jim je zato treba omogočiti tudi pozneje. Zanašal se je na ugodne učinke kulturno-prosvetnega dela med prebivalstvom.

Prva svetovna vojna je prekinila tradicijo kulturno-prosvetnih društev po vaseh. Zamrli so poskusi prvih ljudskih visokih šol v Trstu, Celju in Mariboru. Izobraževalna društva v novi Kraljevini Srbov, Hrvatov in Slovencev niso bila dobrodošla, ker je vladal strah, da bi ljudi nacionalno prebujala in škodila novi državi. Ljudje so se izseljevali v Ameriko. Svojo potrebo po kulturno-prosvetnem delu in izobraževanju so uresničevali v Buenos Airesu, Clevelandu. Med prvimi zadevami po prihodu v novo domovino so ustanovili kulturno-prosvetna društva. Imenovali so jih po nekdanjih društvih doma: Danica, Jutro, Zarja, Triglav. V okupirani Primorski je fašistična vlada Italije $\mathrm{z}$ enim dekretom zaprla vsa kulturno-izobraževalna društva, njihovo nepremično premoženje in denar na bančnih računih zasegla ter prepovedala slovenski jezik. V obdobju med vojnama je v izobraževanju odraslih vladal boj za obstoj. Zato v tem času niso nastala kaka posebna teoretična ali znanstvena dela s področja izobraževanja odraslih.

Beseda »prosveta « ali »ljudska prosveta « se je pojavila spet na partizanskih mitingih med drugo svetovno vojno kot ena od idej in ciljev osvobodilnega gibanja. Najdemo jo predvsem v besedilih Edvarda Kocbeka in Josipa Vidmarja. Optimizem po končani vojni je bil poln navdušenja nad prosvetnim delom. Leta 1945 je začel izhajati časopis »Prosvetni delavec«. Vladala je splošna socialna klima, da naj ljudje, ki imajo znanje, tega posredujejo ljudskim množicam. Po člankih sodeč, so na teh dogodkih nastopali učitelji, zdravniki, umetniki in politiki. Največ je bilo enkratnih predavanj, razne »proslave «, »mitingi in »povorke« (pohodi ljudi v procesiji skozi mesto, vzklikanje gesel in prepevanje pesmi, prikazi industrijskega dela na prirejenih pomičnih odrih na tovornjakih ali vozovih). Članki v Prosvetnem delavcu dokazujejo, da so bile vsebine blizu ljudem, opisujejo same dogodke in z izobraževanjem tesno povezujejo kulturne programe. Beseda »prosveta « se je pogosto pojavljala. Tako se je nadaljevalo do leta 1949. Takratni politični preobrat v državi je pomenil konec tudi za prosvetno delo. Prosvetni delavec je čez noč postal glasilo Zveze sindikatov Jugoslavije. Od takrat dalje je ohranil samo še svoje ime. Besedila so se z naslednjo številko povsem spremenila. $\mathrm{Na}$ prvih straneh so bili objavljeni politični govori s kongresov sindikatov, poročila $\mathrm{z}$ raznih sestankov in časopis se je povsem spolitiziral. Učitelji pa so ga še naprej dobivali obvezno in brezplačno. Brali so ga le politično zagnani. Pogosto so se med starim papirjem znašli neprebrani izvodi. Še manj so se za spremenjeno publikacijo zanimali preprosti ljudje, saj to ni bil več »njihov « časopis. (Glej arhiv Šolskega muzeja v Ljubljani, Prosvetni delavec od 1946 do 1950.)

Želja po ponovni ustanovitvi kulturno-izobraževalnih društev se je uredila na državni ravni. S posebnim odlokom so bila ustanovljena kul- 
turna društva Svoboda. Živahna so bila nekaj let in zamrla skupaj s Prosvetnim delavcem. S sistemsko urejeno prakso izobraževanja odraslih konec petdesetih let prejšnjega stoletja so v takratni državi spet nastale možnosti za razvijanje raziskovanja in teorije na tem področju. Konec leta 1958 se je, po danskem zgledu ljudskih visokih šol, z državnim odlokom ustanovila mreža delavskih in ljudskih univerz. Vsaka republika je imela svojo zvezo delavskih in ljudskih univerz. Na začetku je bilo njihovo število zelo veliko (v Sloveniji jih je bilo čez 200), nato je postopoma upadalo in danes ima Slovenija le 10 odstotkov začetnega števila teh ustanov. Celo Ljubljana in Maribor je več nimata. Mreža je bila dobro organizirana in je delovala tudi v manjših krajih. Posvečala se je predvsem poklicnemu usposabljanju in pridobivanju formalne šolske izobrazbe odraslih. Razvejena praksa je omogočala sistematična opazovanja in posplošitve. V šestdesetih letih so začeli objavljati prve knjige o izobraževanju odraslih (Krajnc, 1978/1).

Od šestdesetih let prejšnjega stoletja naprej količina literature o izobraževanju odraslih narašča tudi pri nas: posamezne razprave, članki, zborniki odražajo najpomembnejše oblike in programe za odrasle. Cilji izobraževanja odraslih so se spremenili. Pokazalo se je, da je $\mathrm{z}$ industrializacijo izobraževanje odraslih pri nas postalo ožje, namenjeno je predvsem delu, zaposlitvi in je osredotočeno na usposabljanje delavcev za operacije ob stroju. Avtorji Ivan Bertoncelj, Jože Valentinčič in Ivan Kejžar objavljajo članke o prerezu stanja in uspešnih primerih učenja odraslih (Miklič, Bertoncelj, Kejžar, 1969; Bertoncelj, 1963).

Pri študiju andragogike pa smo uporabljali dela Savičevića, Filipovića in Samolovćeva z Univerze v Beogradu in Mihajla Ogrizovića z Univerze v Zagrebu. Ogrizović je sredi šestdesetih let izdal dve za andragoško teorijo temeljni publikaciji: Problemi andragogije (1966) in Metode obrazovanja odraslih (1966).
Istega leta je $\mathrm{v}$ Sarajevu skupina avtorjev (Ogrizović, Samolovćev in drugi) izdala obsežno delo Osnovi andragogije. Kmalu potem, ko je bila andragogika uvedena kot študijski predmet $\mathrm{v}$ programu pedagogika, to je bilo $\mathrm{v}$ začetku sedemdesetih letih prejšnjega stoletja, je v Sloveniji izšlo več učbenikov za študij andragogike (Krajnc, 1976, 1977, 1978, 1978/2, 1982; Valentinčič, 1972). Naštela sem le nekaj izhodiščne literature. Pozneje se je količina strokovne literature v andragogiki povečevala in avtorji so se posvečali že bolj posebnim strokovnim temam, kar so omogočale predvsem nove raziskave. Morda pa so nas podatki o prvih knjigah prepričali, da andragogika ni več tako mlada veda, kot nekateri radi poudarjajo (Ogrizović, 1966 in 1966/1; Ogrizović, Samolovćev in drugi, 1966).

Ko sem dela domačih avtorjev zatem primerjala z deli tujih piscev, sem ugotovila, da so prva in druga odraz spremljajoče se stvarnosti v praksi. Domača dela so obravnavala izobraževanje odraslih v funkciji industrijskega dela in produktivnosti. Tuji avtorji so perspektive izobraževanja odraslih zastavili mnogo širše in poudarjali še druge funkcije učenja, saj so že izhajali iz teorije vseživljenjskega izobraževanja Paula Lengranda. Bralec je pri tujih avtorjih zaslutil iskanje neke nove stvarnosti. Veliko je bilo iskanj in eksperimentov. Pojavljale so se novosti $\mathrm{v}$ povezavah izobraževanja odraslih s kulturnimi ustanovami (vloga knjižnic v izobraževanju odraslih, muzejska andragogika, družinska andragogika, gledališče kot izobraževalna metoda), športom (športna andragogika), društvi (izobraževalni tabori, poletne šole), samoorganiziranimi skupnostmi in priložnostnimi druženji (izobraževalni turizem).

Zveza izobraževalnih centrov $\mathrm{v}$ podjetjih je med letoma 1975 in 1990 izdajala manjše glasilo Novice. Po osamosvojitvi Slovenije je zveza ugasnila. Izdajanje Novic je nadaljeval novoustanovljeni Andragoški center Slovenije (ACS). Tiskane Novice so leta 2010 nadomestile elektronske. 
Pomembno dopolnilo k strokovnim knjigam so vedno znanstvene in strokovne revije. Majhna naklada strokovnih knjig v majhnih jezikovnih skupnostih ni privlačna za založbe. Za knjižno izdajo izsledkov neke raziskave je potrebnega precej časa in naporov. Zato ima lahko tukaj pomembno vlogo strokovna revija, ki sproti objavlja članke in razširja nova znanja med strokovnjaki svojega področja. V projektu EU za razvoj nacionalnih revij za izobraževanje odraslih $\mathrm{v}$ Srednji in Vzhodni Evropi, koordiniralo ga je finsko združenje za izobraževanje odraslih iz Helsinkov pod vodstvom Tima Toivinianena (1994-1996), smo tudi v Sloveniji začeli izdajati prvo slovensko strokovno znanstveno revijo za izobraževanje odraslih »Andragoška spoznanja«. Revija izhaja od leta 1995 dalje pri Filozofski fakulteti v Ljubljani, in sicer štirikrat na leto v skupnem obsegu okoli 400 strani znanstvenih in strokovnih člankov. Pretok strokovnega znanja je s tem dobil nove možnosti. Revija prinaša znanstvene novosti in odmeve iz uspešne prakse, spremlja pomembnejše strokovne dogodke in obletnice, delno služi kot študijska literatura pri študiju andragogike na univerzah v Ljubljani, Mariboru in v Kopru, namenjena pa je tudi praktikom. Najpogostejši naročniki so strokovnjaki v andragoški praksi in ustanove, ki se kakorkoli ukvarjajo z vzgojo in izobraževanjem odraslih. Širok krog avtorjev in bralcev ji daje vitalno vlogo v razvoju izobraževanja odraslih pri nas.

\section{KAKO SE JE ŠTUDIJ ANDRAGOGIKE V SLOVENJI RAZVIJAL KRONOLOŠKO?}

Bližal se je čas, ko sem morala za študij pedagogike na Filozofski fakulteti v Ljubljani dokončno pripraviti študijski program za dva nova andragoška predmeta, občo andragogiko in andragoško didaktiko. Predavanja sem morala začeti v študijskem letu 1972/73, takoj po vrnitvi s postdoktorskega študija na Ontarijskem inštitutu za raziskovanje vzgoje in izobraževanja (Ontario Institute for Studies in Education, OISE) pri Univerzi v Torontu. Ob spoznavanju domače in tuje prakse ter strokovne literature sem zagledala dve podobi izobraževanja odraslih: domačo $\mathrm{v}$ deželi $\mathrm{v}$ razvoju (takratni Jugoslaviji) in tujo v razvitih državah; te so že takrat odkrivale zakonitosti postindustrijske ali informacijske družbe.

Študijski program naj bi prinesel čim več novega, omogočil naj bi, da se andragoška praksa razvije do te mere, da usposablja odrasle za sedanjost in prihajajočo prihodnost. Sledil naj bi raziskavam o izobraževanju odraslih $\mathrm{v}$ razvitejšem svetu in hkrati naj bi ustrezal domačim razmeram, bil vraščen vanje in prinašal nova andragoška znanja, uporabljiva v praksi. Pri sestavljanju študijskega programa sem morala upoštevati teoretično in znanstveno tradi- cijo pedagogike na Oddelku za pedagogiko. To mi ni bilo težko, ker sem tudi sama diplomirala po tem programu.

Pri sestavljanju študijskega programa se je med seboj križalo več vplivov. Nekatere teme sem zavestno izločila: individualizacijo izobraževanja odraslih, osebne učne projekte, kvalitativno metodologijo raziskovanja, izobraževalno svetovanje, komparativno andragogiko itd., ker jih naša stopnja razvoja andragoške prakse takrat še ni dosegala.

Študenti prvega in drugega letnika so poslušali občo andragogiko, v tretjem letniku pa andragoško didaktiko. Poleg predavanj so pri obči andragogiki študenti na seminarju predstavili svoje seminarske naloge in se tako poglobili v izbrano temo. Razen slovenske literature so uporabljali še knjige v srbohrvaščini, nemščini in angleščini. V stalnih stikih smo bili z univerzama v Zagrebu in Beogradu. Tesno smo sodelovali z oddelkom za pedagogiko odraslih na pobrateni univerzi v Tübingenu v Nemčiji (Günter Dohmen) in fakulteto za izobraževalne vede v Londonu (Colin Titmus).

Razvoj izobraževalnih ved je napredoval. Leta 1976 je v strokovnih krogih nastala pobuda, da bi se na Oddelku za pedagogiko uvedli še nekateri novi predmeti. Odločili smo se, da bomo študij pedagogike razdelili v nekaj smeri. S takratnim uvajanjem domske pedagogi- 
ke bi bil namreč enoten študij z vsemi novimi predmeti (šolskim svetovalnim delom, domsko pedagogiko, industrijsko andragogiko, metodiko družbenopolitičnega izobraževanja, svetovanjem za osebnostni razvoj) odločno preobsežen. Zato se je študij pedagogike s študijskim letom 1976/77 razdelil v tri študijske smeri: šolska pedagogika, domska pedagogika in andragogika. Predvidena je bila še četrta smer: predšolska pedagogika, a ni nikoli zaživela. Diploma je ostala enotna z oznako izbrane smeri študenta v oklepaju. Andragogika se je razdelila na nekaj kateder. Novo katedro za industrijsko andragogiko in metodiko družbenopolitičnega izobraževanja je vodil profesor Ilija Mrmak z asistentom Jankom Muršakom. Na andragoški smeri se je podvojil predmet andragoška didaktika, uvedena je bila komparativna andragogika in nekaj novih predmetov: andragoško svetovalno delo, industrijska andragogika. Vse tri smeri so delovale na enotnem oddelku za pedagogiko do srede osemdesetih let prejšnjega stoletja, ko se je domska pedagogika »preselila« na Pedagoško fakulteto Univerze v Ljubljani in je tam postala samostojen študij: socialna pedagogika. Andragoška smer in smer šolske pedagogike pa sta ostali naslednjih 15 let. V drugi polovici osemdesetih let so bili pritiski za skolarizacijo izobraževanja zelo močni: industrijska andragogika je prešla $\mathrm{v}$ poklicno pedagogiko in andragogiko (Muršak). Nadomestila jo je pedagogika poklicnega izobraževanja.

Leta 1992 smo na Centru za razvoj univerze pri Univerzi v Ljubljani, ki sem ga $\mathrm{v}$ tistem času vodila, pridobili tri evropske TEMPUSOVE projekte: Računalniško podprto delovanje univerze (koordinator S. Vilfan), Kvaliteta visokošolskega študija (koordinatorica Barica Marentič Požarnik) in Prenova študija andragogike (koordinatorica Ana Krajnc). Slovenija takrat še ni bila članica EU, zato smo sodili v posebno kategorijo TEMPUSOVIH projektov EU. Velika prednost je bila v tem, da smo pri vseh treh projektih mi bili tudi koordinatorji in so bile univerze drugih držav naše partnerice. Tako smo laže načrtovali in tudi uresničevali delo v projektih, prilagojeno našim potrebam, da je bilo neposredno koristno za naše nove razmere v samostojni Sloveniji. Pri evropskih partnerjih smo odkrili veliko pripravljenost za sodelovanje. Vladala je pozitivna socialna klima v podporo novonastali državi.

Osredotočila se bom na projekt Prenova študija andragogike, kjer so bile partnerske univerze: Univerza v Surreyu (koordinator Peter Jarvis), Univerza v Bambergu (koordinator Jost Reischmann), San Patric College na Irskem (koordinator Liam Carey) in Univerza v Utrechtu (koordinator P. Hage). Skupaj smo pripravljali program za samostojen enopredmetni študij andragogike in diplomo $\mathrm{z}$ nazivom diplomirani andragog. Novi program za samostojni študij andragogike je šel skozi vse potrebne postopke na ministrstvu za šolstvo in šport, pri fakultetnih in univerzitetnih organih. Spomladi leta 1993 ga je potrdil tudi svet Univerze v Ljubljani. Jeseni v študijskem letu 1993/94 se je vpisala prva skupina študentov andragogike kot samostojnega enopredmetnega študija. Sočasno je bil sprejet tudi program enopredmetnega samostojnega študija pedagogike; ker so kolegi izhajali iz potreb šole, je pedagogika poleg tega ohranila tudi dvopredmetno obliko študija. Na oddelku smo torej pridobili dva samostojna, enopredmetna študija: andragogika in pedagogika.

Pri novih predmetih smo računali $\mathrm{z}$ izvolitvijo novih docentk in enega docenta, direktorja Andragoškega centra Slovenije, Zorana Jelenca. Ker so formalni postopki še tekli in da bi bil naš začetek študija samostojne andragogike čim bolj kakovosten, so v okviru TEMPUSOVEGA projekta prvo študijsko leto 1993/94 kot gostujoči profesorji predavali vsi koordinatorji partnerskih univerz $\mathrm{v}$ projektu: Peter Jarvis, Liam Carey, Jost Reischmann in Colin Titmus. S tem smo v izvajanje študija pritegnili za teorijo o izobraževanju odraslih najbolj znane znanstvenike in profesorje $\mathrm{v}$ 
Evropi z lepim številom objavljenih knjig. Ker so se nam zdela predavanja gostujočih profesorjev zelo dragocena in nismo vedeli, kdaj se nam bo v prihodnje še ponudila priložnost, da znane profesorje lahko poslušamo kar doma, smo njihova predavanja organizirali $\mathrm{v}$ večji predavalnici na Andragoškem centru Slovenije in povabili k udeležbi tudi strokovnjake iz prakse. Predavanja so bila sicer v angleščini. Rednim izvajalcem študija andragogike se je pridružil doc. dr. Zoran Jelenc in kmalu nato še doc. dr. Vida Mohorčič (doktorirala v okviru omenjenega TEMPUSOVEGA projekta), oba z Andragoškega centra Slovenije. Meni (obča in komparativna andragogika), doc. dr. Janku Muršaku (poklicna andragogika) in doc. dr. Neni Mijoč (andragoška didaktika) so se postopoma pridružile še: doc. dr. Dušana Findeisen (sociokulturna animacija), doc. dr. Sabina Jelenc (andragoško svetovalno delo in andragogika ciljnih skupin), doc. dr. Sonja Kump (komparativna andragogika), doc. dr. Nives Ličen (obča andragogika in družinska andragogika) in doc. dr. Monika Govekar Okoliš (zgodovina izobraževanja odraslih in obča andragogika za pedagoške smeri drugih študijev). Predmet informatika in računalništvo v izobraževanju odraslih je oblikoval in predaval doc. dr. Denis Trček z Inštituta Jožefa Štefana. Ob uvedbi samostojnega študija andragogike je nastala poleg prejšnjih dveh (katedre za občo in komparativno andragogiko, vodja Ana Krajnc, in katedre za poklicno pedagogiko in andragogiko, vodja Janko Muršak) še tretje katedra za andragoško didaktiko (vodja doc. dr. Nena Mijoč).

Po uvedbi dveh smeri samostojnega študija se je leta 1995 dotedanji Oddelek za pedagogiko tudi uradno preimenoval v Oddelek za pedagogiko in andragogiko. Tak naziv je ohranil do danes.

Leta 1998 je fakulteta pod vodstvom dekanje prof. dr. Neve Šlibar iz nepojasnjenih razlogov odpravila naziv diplomirani andragog, ne da bi se sploh posvetovala s takratno predstojnico
Oddelka za pedagogiko in andragogiko in snovalko študija, prof.dr. Ano Krajnc, ali jo kakorkoli obvestila. Informacijo je predstojnica odkrila slučajno in po neformalni poti. Kakršenkoli nadaljnji pogovor o tej temi je dekanja kategorično zavrnila. Še do danes mi ni znano, kaj je bilo v ozadju take odločitve. Besede in nazivi se mi ne zdijo najpomembnejši, stvari presojam po dejanjih. Zato nisem izgubljala energije in časa $\mathrm{z}$ raziskovanjem negativnih manipulacij $\mathrm{v}$ ozadju odločitve za odpravo naziva »andragog « v diplomi samostojnega študija andragogike. Najpomembneje se mi je zdelo, da so andragogi čim boljši strokovnjaki in čim bolj kompetentni za prihodnje odgovornosti pri delu, da dohitevajo svetovni razvoj stroke in znanosti, pa naj imajo tak ali drugačen naziv. Brez ustreznega naziva so se diplomantom delno skrčile možnosti zaposlovanja. Ker se je obseg prakse večal in je bila zahteva po kakovostnem in profesionalno vodenem izobraževanju odraslih vedno bolj glasna, je tudi upad v zaposlovanju postopoma izzvenel.

\section{ANDRAGOGIKA NA DRUGIH UNIVERZAH V SLOVENIJI}

V zadnjem času se je Oddelku za pedagogiko in andragogiko Filozofske fakultete v Ljubljani pridružil še doc. dr. Marko Radovan. Na Univerzi na Primorskem predava andragogiko doc. dr. Maja Mezgec, sicer direktorica Slovenskega znanstvenega inštituta $\mathrm{v}$ Trstu. Za učitelja andragogike v Mariboru se pripravlja študentka doktorskega študija Senka Hočevar Ciuha. $\mathrm{Na}$ druge univerze v Slovenji se je andragogika razširila predvsem v okviru Pedagoško- andragoškega izobraževanja za bodoče učitelje srednjih šol in predmetnega pouka v osnovnih šolah. Strokovnjaki, diplomanti nepedagoškega študija na drugih fakultetah, si s tem študijskim modelom pridobijo licenco učitelja. Po zakonu iz leta 1981 je v Sloveniji andragogika eden od štirih temeljnih predmetov (poleg pedagogike, didaktike in specialne didaktike) 
pedagoško-andragoškega izobraževanja (PAI). Opisani študijski model traja dva semestra. V letih 2007-2008 je bil ta model vsebinsko prenovljen, dodani so mu bili še nekateri izbirni predmeti (retorika, socialne veščine) in opazovalna praksa.

Prav pod vplivom PAI se je andragogika kot veda razširila tudi med diplomante drugih fakultet in je imela velik vpliv na popularizacijo teorije permanentnega ali vseživljenjskega izobraževanja v Sloveniji, na nastajanje učeče se družbe in širjenje izobraževanja $v$ vse pore našega družbenega in osebnega življenja. Tako so v novih strokovnih okoljih nastale nove aplikacije andragogike, kar je obogatilo tudi samo vedo.

Oddelek za pedagogiko na Univerzi v Mariboru se razvija in predvidevamo, da bodo v prihodnje uvajali tudi nove predmete. Med drugim bosta gotovo postopoma zaživela samostojna predmeta pedagogika in andragogika, zdaj se še vedno predavata skupaj. Mezirow, profesor na Columbia University v New Yorku, loči genotipsko ali šolsko izobraževanje kot podlago za sekundarno socializacijo otrok v šoli po zahtevah družbe od fenotipskega izobraževanja, sprotnega izobraževanja, nastalega kot odziv na spremljajoče situacije (izobraževanje odraslih). Dva povsem nasprotna pristopa $\mathrm{k}$ izobraževanju. Če bi ju pomešali ali poskušali poenotiti, bi vsak od njih izgubil svoje bistvo.

\section{ZAKLJUČEK}

Uvajanje študija andragogike na Univerzi v Ljubljani je zgodba uspeha in resničnih dosežkov. Ne bi bilo povsem naravno, če ne bi v zakulisju delovale tudi razvoju nasprotne sile. Probleme imamo vsi ljudje, pravi Erik Bern v knjigi Katero igro igraš?. Razlikujemo se po tem, ali se osredotočimo na zmage ali izgube. Zmagovalci se osredotočijo na zmage, dosežke.
Zgubarji se največ ukvarjajo z ovirami in izgubami, zato se vedno bolj oddaljujejo od ciljev, namesto da bi se jim vztrajno približevali kot zmagovalci (Bern, Erik, 1980).

Nasprotovanja in ovire na poti do cilja, da razvijemo študij andragogike, smo pretežno puščali ob strani. Bolj smo se zanašali na podporo in sodelovanje. Naj dejstva govorijo o tem, koliko smo napravili in kako daleč nam je uspelo priti.

Gospodarska in finančna kriza je kriza vrednot, je dokončna revolucija znanja. Zadnja svetovna UNESCOVA konferenca o izobraževanju odraslih nam je začrtala pot iz krize: postavite ljudi na prvo mesto. Potem, ko se bodo prevrednotile vrednote, bo izobraževanje in zdravstvo na prvem mestu. Kakovostnih učiteljev in zdravnikov nam že danes manjka.

Kakovost študija andragogike se med drugim spozna tudi po primernem povezovanju s sorodnimi strokami: psihologijo, sociologijo in ekonomijo. Izobraževanje odraslih je fenotipsko (Mezirow). Odziva se na nastale situacije $\mathrm{v}$ javnem in zasebnem življenju. Pričakujemo timsko delo več vrst strokovnjakov. Interdisciplinarni pristop namesto delitve na discipline je bliže resničnosti. Problemi so vedno interdisciplinarni. Ljudje od znanja pričakujejo rešitev. Pričakujemo, da bo šel nadaljnji razvoj po dveh navidezno nasprotujočih si poteh: poti interdisciplinarnih pristopov $\mathrm{v}$ izobraževanju in hkrati po poti vedno večje specializacije.

\section{LITERATURA}

Adam, F. (1987). Andragogia y docencia universitaria. Caracas: Fondo Editorial de la Federacion interamericana de educacion de adulto.

Bern, E. (1980). Koju igru igraš? Beograd: Nolit. Bertoncelj, I. (1963). Preizkus znanja. Ljubljana: Zavod SRS za strokovno izobraževanje.

Bertoncelj, I. (1966). Metoda za izdelovanje profilov in učnih načrtov. Ljubljana: Zavod za šolstvo SRS.

Bertoncelj, I. (1966). Programiranje seminarjev in tečajev. Ljubljana: Zavod za šolstvo SRS.

Chamberland, E. (ured.) (1995). L'andragogie, 
Actes de celebrations du 25 e anniversaire de l'andragogie a l'universite de Montreal. Montreal: Universite de Montreal.

Charnley, A. H. (1974). Research in Adult Education in the British Isles. London: National institute for Adult Education, NIAE.

David, M. (1962). Adult Education in Yugoslavia. Pariz: UNESCO.

De Sanctis, F. M. (1978). L'educazione degli adulti in Italia. Roma: Editori riuniti.

Dohmen, G. (1996). Lifelong Learning. Berlin: Zvezno ministrstvo za izobraževanje, znanost, raziskave in tehnologijo.

Felix, A. (1987). Andragogia, Ciencia de la educecim de adultos. Caracas: Editorial andragogic C. A.

Filipović, D. (1971). Permanentno obrazovanje, suština i konsekvence. Leskovac: Naša reč.

Freire, P. (1970). Pedagogy of the Oppressed. New York: HerdeR and Herder.

Govekat, M.; Ličen, N. (2008). Poglavja iz andragogike. Ljubljana: Znanstvena založba Filozofske fakultete.

Gradivo simpozija o Matiji Vertovcu (1984). Goriški letnik 11.

Komensky, J. A. (1970). Pedagogija 1/1970. Beograd.

Jelenc, S. (1996). ABC izobraževanja odraslih. Ljubljana: ACS.

Jug, J. (1995). Izobraževanje odraslih in socialna gibanja v Sloveniji, Zgodovina izobraževanja odraslih, II. zv. Kranj: Moderna organizacija.

Kaplan, A. (1995). Andragogika kot pedagoška znanost na pedagoškem študiju na Hrvatskem, Zgodovina izobraževanja odraslih, II. zv. Kranj: Moderna organizacija.

Kidd, R. J. (1971). How Adults Learn. New York: Association Press.

Knoll, J. H. (ured.) (1985). Motivation for Adult Education. Bonn: German commission for UNESCO.

Komensky, J. A. (1992). V̌̌evychova/Pampadeia. Bratislava: Vidavatelstvo obzor.

Krajnc, A.; Findeisen, D. (1995). Matija Vertovec kot prosvetni delavec, Zgodovina izobraževanja odraslih, II. zv., Zgodovina izobraževanja odraslih v Srednjeevropskih državah. Kranj: Moderna organizacija: 95-107.

Krajnc, A. (1973). Adult Education and Social Participation. Toronto: OISE.

Krajnc, A. (1973). Attitudes toward Education and Social Participation. Toronto: OISE.

Krajnc, A. (1976). Andragoški pogovori s predavatelji. Ljubljana: Zveza delavskih univerz Slovenije.

Krajnc, A. (1977). Izobraževanje naša družbena vrednota. Ljubljana: Delavska enotnost.

Krajnc, A. (1978). Metode izobraževanja odraslih. Ljubljana: Delavska enotnost.

Krajnc, A. (1978/1). Izobraževanje ob delu. Ljubljana: Univerzum.

Krajnc, A. (1982). Motivacija za izobraževanje. Ljubljana: Delavska enotnost.

Krajnc, A.; Ličen, N. (1995). Adult Education in Slovenia, International perspectives in Adult Education, No 34. Bonn: Institute for International Cooperation, DVV.

Krajnc, A.; Mrmak, I. (1978). Adult Education in Yugoslavia, Adult Education in Europe, No 4. Praga: UNESCO Center for Leisure and Education.

Ličen, N. (2009). Uvod v izobraževanje odraslih. Ljubljana: Znanstvena založba Filozofske fakultete.

Matijević, M. (1984). Učimo uz rad. Zagreb: OOUR Centar za dopisno obrazovanje, Zavod Birotehnika.

Medveš, Z.; Muršak, J. (1993). Poklicno izobraževanje - problemi in perspektive. Ljubljana: Slovensko društvo pedagogov in Znanstveni inštitut Filozofske fakultete.

Miklič, Bertoncelj, Kejžar (1969). Pripravništvo in pripravniki. Ljubljana: Časopisni zavod Uradni list SR Slovenije.

Ogrizović, M. (1966). Metode obrazovanja odraslih. Zagreb: Radničko sveučilište Moša Pijade.

Ogrizović, M. (1966). Problemi andragogije. Zagreb: Savez narodnih sveučilišta Hrvatske.

Ogrizović, M. (1966). Osnovi andagogije. Sarajevo: Zavod za izdavanje učbenika.

Ozvald, K. (1927). Kulturna pedagogika. Ljubljana: Slovenska šolska matica.

Petančič, M. (1968). Industrijska pedagogija. Beograd: Radnički univerzitet Novi Beograd.

Rogers, C. R. (1969). Freedom to Learn. Ohaio: Charles E. Merrill Publishing Company, Columbus.

Samolovćev, B.; Muratbegović, H. (1979). Opšta andragogija. Sarajevo: Veselin Masleša.

Savičević, D. (1984). Komparativno proučavanje vaspitanja i obrazovanja. Beograd: Filozofski fakultet.

Savičević, D. (2003). Komparativna andragogija. Beograd: Inštitut za pedagogiju i andragogiju FF.

Savičević, D. (ured.) (1965). »Sistem obrazovanja odraslih«. V: Medžunarodni seminar o sistemu obrazovanja odraslih. Opatija.

Škoda, K. (1995). Izobraževanje odraslih v čeških deželah v obdobju prosvetljenstva, Zgodovina izobraževanja odraslih, II. zv. Kranj: Moderna organizacija.

Tough, A. ( 1971). The Adult's Learning Projects. Toronto: OISE. 
Valentinčič, J. (1973). Osnove andragogike. Ljubljana: DDU.

Vidmar, T. (1995). »Ideja permanentnega izobraževanja pri J. A. Komenskem v delu Pampadeia «. Andragoška spoznanja, 1-2: 48-55.

Žgeč, F. (1923). Problemi vzgoje najširših

plasti našega naroda. Ljubljana: Udruženje jugoslovenskega učiteljstva. 